\title{
O romance 'Homens e caranguejos' de Josué Castro: A contemporaneidade no tempo narrativo da memória
}

Thiago Azevedo Sá de Oliveira ${ }^{1}$

O ‘marco-multidimensional' do contemporâneo: as imagens simultâneas da narrativa

“Claro canário canta o amarelo dos cajás. O canto ácido (o trino de ágata) corta a tarde e martiriza as cajazeiras com seus frutos de tempo.

O tempo corrompido. E a ferrugem nos dentes das moendas lança um grito.

As moendas revivem e seus dentes mordem (cana sobrevivente) a terra.

O tempo corrompendo. E as lembranças reacesas nas fornalhas e revivas ruínas. Melões-de-são-caetano sobem a vertical tristeza dos boeiros. O tempo corrompido e corrompendo. O tempo antitempo renascendo." (Garibaldi Otávio) ${ }^{2}$

\footnotetext{
1 Mestrando em Estudos Literários pelo Programa de Pós-Graduação em Letras da Universidade Federal do Pará (UFPA). Bolsista CAPES.

${ }^{2}$ Otávio, 2009, p. 16. 
Oliveira, Thiago Azevedo Sá de. O romance 'Homens e caranguejos' de Josué Castro: A contemporaneidade no tempo narrativo da memória.

Na contemporaneidade, período às avessas cuja "marca" identitária se constitui no abalo das formas estáveis de ação e de interpretação do homem no mundo, abre-se, com efeito, a ideia da brevidade e de fragmentação da memória como fissuras que incomodam e "acomodam", ao menos momentaneamente, a configuração estética do cronos. No entorno dos romances afinados com a dimensão transitória do real se dando e se esvaindo sempre novo no espaço figurado da linguagem, o texto de Homens $e$ caranguejos, escrito originalmente em francês, no ano de 1966, por Josué de Castro, durante o exílio em Paris e, traduzido no ano seguinte para o português, emerge na tentativa de dar conta da metáfora que transforma o topos do mangue em elemento espácio-temporal simbólico do devir.

Ao desenvolver o enredo no argumento dramático do sujeito excluído, à margem do progresso da cidade, a trama josueniana convida os leitores à reflexão sobre as fomes não saciadas de igualdade, de justiça e de liberdade, encenadas nas provocações e desejos do menino João Paulo. Escrita nos 'anos de chumbo' do golpe militar brasileiro, a ficção eleva à transversalidade do artístico, o propósito de recompor, tais quais suas intenções, o mosaico figurado entre a história e o imaginado, de vontade e de silêncio, nos borrões de lama, de onde trabalham e sonham os homens-caranguejos da Aldeia Teimosa (microcosmo do Recife).

Repercutindo o que Zygmunt Bauman, em Modernidade líquida(2001)³, insinua como a dinâmica de uma "modernidade sólida" que é tornada fluída para erigir uma transição, a "modernidade líquida", o romance, com a 'boca' apontada para

${ }^{3}$ Compatível à noção apresentada por Marx e Engels desde o século XIX por intermédio da frase "Tudo que é sólido se desmancha no ar". Cf. Berman, 1986.

${ }^{4}$ Sobre a "modernidade líquida, fluida”, Bauman (2001, p. 13) atina: "O que está acontecendo hoje é, por assim dizer, uma redistribuição e realocação dos "poderes do derretimento" da modernidade. Primeiro, eles afetaram as instituições existentes, as molduras que circunscreviam o domínio das ações - escolhas possíveis, como em estamentos hereditários com sua alocação por atribuição, sem chance de apelação. Configurações, constelações,

Brasiliana - Journal for Brazilian Studies. Vol. 3, n.1 (Jul. 2014). ISSN 2245-4373. 
Oliveira, Thiago Azevedo Sá de. O romance 'Homens e caranguejos' de Josué Castro: A contemporaneidade no tempo narrativo da memória.

Pernambuco e com os dentes afiados para o 'mundo', expande vicariamente o instável de forma lúdica, múltipla e refratora, onde os elementos estruturais do tempo e do espaço se articulam, formando junto aos demais o todo linguístico, significativo e coerente da obra literária.

Fraturando, a priori, as características da brevidade e da concisão da linguagem entre gêneros distintos, isto é, do conto “O ciclo do caranguejo" $(1935)^{5}$ para o prefácio que articula os possíveis insumos do romance Homens e Caranguejos (1967), esta composição escrita pelo autor pernambucano do mundo ${ }^{6}$, aqui tomada para apreciação crítica, empenha-se em mediar o espectro de imagens do tempo-espaço sedimentadas no entorno de duas hipóteses metodológicas mais salientes: o olhar difuso e efêmero do contemporâneo, sobre o elemento fragmentado das memórias dos personagens, e a relação de interdependência constituída na conceituação bakhtiniana do cronotopo.

Ao compor a matéria narrativa, espacialidade e temporalidade, signicamente unidas e em movimento, repercutem na obra josueniana um efeito sine qua non de deslocamento e de simultaneidade entre o real orgânico e biológico do mangue em transformação e a ficção do ser-no-mundo de metamorfose imaginada. Gérard Genette em Discurso da Narrativa (1995, p. 34), aponta para o aspecto da anacronia, isto é, de "discordância entre a ordem da história e a da narrativa", corroborando para o

padrões de independência e de interação, tudo isso foi posto a derreter no cadinho, para ser depois novamente moldado e refeito; essa foi a fase de "quebrar a forma" na história da modernidade inerentemente transgressora, rompedora de fronteiras e capaz de tudo desmoronar."

${ }^{5} \mathrm{~A}$ fim de realçar os traços que põem em lados opostos o conto e o romance, Cortázar compara-os, concomitantemente à fotografia e ao cinema. Assim mensura o caráter restrito no conto e focaliza o zoom no romance. Cf. Cortázar, 1993, p. 151-2.

6 “De Josué de Castro e sua obra de escritor e cientista (...) ouvi falar, tanto em Paris como em Moscou, tanto em Viena e Berlim quanto em Pequim e Ulam Bator, cidade encravada nas montanhas da Mongólia. Por toda a parte onde se lê e o trabalho da inteligência é respeitado e amado". (Amado, 1958, p. 347-349).

Brasiliana - Journal for Brazilian Studies. Vol. 3, n.1 (Jul. 2014). ISSN 2245-4373. 
pensamento da contemporaneidade às voltas com a imagem de celeridade, mutação e descompasso.

Entre a terra e a água, os homens e os bichos, sucedem e se antecipam ao nível linear do discursivo, sobremaneira irritado pelo cruzamento de diálogos em tempos e espaços distintos da memória, discursos diretos e digressões da personagem e do narrador, encadeando uma focalização temporal explicitamente traduzível pelas lentes de zoom das narrativas cinematográficas. O tempo é lacunar e progressivo. Preenche um intervalo, pois aproxima, ao invés de distanciar, a vida da arte. Flagra-se o presente projetando o futuro, ciente de que o agora já se faz passado.

Neste 'vazio aparente', o leitor, apoiado pelas concessões do narrador onisciente em terceira pessoa, 'toca' os personagens do menino João Paulo, Cosme - o paralítico, Zé Luís, Padre Aristides, Seu Maneca, Negra Idalina, Mateus - o vermelho, dentre outros. O narratário recua e progride com as figuras narradas na Aldeia Teimosa, no Recife, no sertão, na Amazônia e nos espaços rememorados ou imaginados no espaçotempo da consciência interior, dividindo a impressão, tal pondera Abdala Júnior, de que “essa(s) personagem(ns) estivesse(m) falando oralmente” (1995, p. 58).

Na minha arrogância que me fazia sentir dono do mundo, eu nunca esperara ser derrubado pelo beribéri, embora tivesse notícia que milhares de outros seringueiros tinham sido atacados dessa estranha doença que, naquela época, ninguém sabia o que era e que, hoje, se sabe ser uma doença da fome. (Castro, 1967, p. 65). ${ }^{7}$

\footnotetext{
${ }^{7}$ Discurso de rememoração do personagem Cosme - o paralítico, No capítulo IV —De como o chão fugiu debaixo dos pés dos milionários da borracha.
} 
Oliveira, Thiago Azevedo Sá de. O romance 'Homens e caranguejos' de Josué Castro: A contemporaneidade no tempo narrativo da memória.

No terreno movediço e tangente do mangue, partem os 'fios' do tempo cronológico, acenando para o contexto instintivo de bilhões de famintos homens-caranguejo e, o ruído do tempo da narração, enriquecido formalmente pela instabilidade deslocadora da memória. Supõe-se realimentar de esperança a vida da humanidade, desatando-a do ostracismo natural e a pondo no universo igualmente humano do estético. Procurando ver nas fomes de justiça a liberdade das personagens, o romance expande o cenário de opressões éticas e existenciais que parecem incorruptíveis na cena real. Como adendo, Ricœur reforça que “...não temos nada melhor que a memória para significar que algo aconteceu, ocorreu, se passou antes que declarássemos nos lembrar dela" (2007, p. 40). ${ }^{8}$

O tempo nesse sentido ocupa a função de sustentar os gestos de vergonha da fome, catástrofe capaz de silenciar como um tabu. Nesse sentido, Salgueiro, ecoa a “impossibilidade radical de re-apresentação do vivido/sofrido" (2012, p. 289), de narrar o que Estêve esclarece como sendo “pour le Brésilien est une honte nationale" (1972, s/n). Desajeitado e lutando com as palavras, a personagem de Zé Luís escava nas lembranças que preserva dos anos da grande seca de 1877, data cronológica de uma das mais alarmantes tragédias vivenciada pela gente do nordeste brasileiro, aqui desdobrada no signo da diegese como um dos pontos de contato entre a factualidade e a imaginação:

- História de fome não é história que se conte - começou Zé Luís - , é só tristeza. Tristeza e vergonha. História feia. Mas, se vocês querem, eu conto assim mesmo. Conto a tristeza e a vergonha que a gente passou na

\footnotetext{
${ }^{8}$ Candido apud Bady (1985, p.18) acrescenta: "A propósito, e para evitar equívocos, mencionemos um trecho de Sainte-Beuve, que parece exprimir exatamente as relações entre o artista e o meio: "O poeta não é uma resultante, nem mesmo um simples foco refletor; possui o seu próprio espelho, a sua mônada individual e única. Tem o seu núcleo e o seu órgão, através do qual tudo o que passa se transforma, porque ele combina e cria ao devolver à realidade."
}

Brasiliana - Journal for Brazilian Studies. Vol. 3, n.1 (Jul. 2014). ISSN 2245-4373. 
seca de 1877. [...] Até então, a gente vivia feliz no sertão de Cabaceiras. (Castro, 1967, p. 72).

Ajustada a meditação de Eric Auerbach sobre a fisionomia concedida ao tempo nas narrativas contemporâneas, em Homens e caranguejos "o tempo da narração não é empregado para o processo em si - este é reproduzido com bastante brevidade —, mas para as interrupções" (2002, p. 484). Os eventos da seca, do movimento migratório das pessoas, do 'burburinho' dos mocambos do Recife irrompem no tecido incompleto da fabulação como 'pontes' de tensão.

Dando acesso para que a narrativa apanhe os fatos de forma análoga ao que discute Eliana Calado, em estudo sobre a ficção As pessoas dos livros (2000), de Fernanda Young, isto é, como "uma sequência de acontecimentos práticos servindo de pretexto ao desencadeamento de pensamentos, lembranças e sensações, que ocupam a maior parte do romance" (2004, p.46), a obra escrita por Josué de Castro partilha do raciocínio atual que elege, no traço opaco da multiplicidade, uma das marcas indeléveis que responde à organização do mundo de modo sintético e indireto, já que “hoje em dia não é mais pensável uma totalidade que não seja potencial, conjectural, multíplice", resume Calvino (1990, p. 131).

\section{Cronotopia-mangue: além do circuito do enunciado, o tempo-espaço da enunciação}

Com a publicação dos ensaios remotos, compilados postumamente na coletânea de Questões de Literatura e de Estética (1975), Mikhail Milkháilovitch Bakhtin (1895-1975), contempla seus direcionamentos acerca dos efeitos da indissociabilidadedas categoriastempo-espaço. Na avaliação que processa, da atuação conjunta dos elementos 
Oliveira, Thiago Azevedo Sá de. O romance 'Homens e caranguejos' de Josué Castro: A contemporaneidade no tempo narrativo da memória.

arquitetônicos e compositivos ${ }^{9}$ e, das vozes discursivas igualmente integradas na estrutura global do romance, o historiador da literatura e filólogo soviético, desenvolve a construção do sujeito enquanto experiência viva da linguagem. Dela, o outro ressoa no diálogo com o eu.

O quesito da enunciação, ponto-chave da filosofia bakhtiniana, concretiza no espaço romanesco, uma perspectiva formal e uma visão de mundo, do sujeito que na linguagem toma consciência de si. Bakhtin acresce, pela nomenclatura de cronotopo ${ }^{10}$ situado na obra de Rabelais, a especulação estratégica da qual, o cronos e o topos cooperam dialogicamente, reorientando a discussão sobre literatura e sociedade - o contexto exterior e a sua expressão reordenada no tecido discursivo.

O autor esboça na experiência do cronotopo uma nova inferência, a de que, no interior do gênero romanesco, índices espaciais e temporais demarcam, ao menos por um instante, a dinâmica que desenha a cronotopia como ferramenta aglutinadora do real (distinto da realidade descritivista dos textos realistas e naturalistas), à linguagem enquanto ato, logo, ação.

Ocorre a fusão dos indícios espaciais e temporais num todo compreensivo e concreto. [...] O tempo condensa-se, comprime-se, tomase artisticamente visível; o próprio espaço intensifica-se, penetra no movimento do tempo, do enredo e da historia. (Bakhtin, 2010, p. 211).

\footnotetext{
9 "Na análise do conteúdo corporal que sustenta a arte e a linguagem, Bakhtin identificou dois aspectos essenciais à compreensão dos elementos estéticos: as formas arquitetônicas e as composicionais. Se aquelas podem ser conhecidas como as peculiaridades que caracterizam o conteúdo e a temática de uma obra, estas são sua própria estrutura, o modo como ela se organiza através dos gêneros e estilos. As arquitetônicas, para Bakhtin, são as que conduzem os valores do homem estético, da natureza e dos fatos. Já as composicionais, por sua vez, carregam em si a impressão artística por meio da organização de seu conjunto verbal” (Melo, 2013, p. 49).

10 "O tempo se derrama no espaço e flui por ele" (Bakhtin, 2010, p. 350).
}

Brasiliana - Journal for Brazilian Studies. Vol. 3, n.1 (Jul. 2014). ISSN 2245-4373. 
Preservando a relação de mão dupla que se assinala na referência espacial e temporal da linguagem espacializada e temporalizada ficcionalmente, em Que é a literatura? Sartre adverte que "existe a palavra vivida e a palavra encontrada" (1989, p. 19), encontrando o que Bakhtin sustenta-se no plano de uma "ubiquidade social das palavras" (1995, p. 41), uma formação que apoia o cronotopo no terreno híbrido e complementar do éticoestético, em planos do passado-presente-futuro.

Em Homens e caranguejos, a mudança que se dá nos espaços alusivos a Pernambuco (sertão, zona da mata, litoral) e à Amazônia - tempo histórico, para a faixa insular do mangue - tempo em mutação, dialogicamente confere a cronotopia um dos papéis de destaque na arquitetura formal e simbólica deste romance.

Como se extraísse das imagens do espaço os planos da recordação e do avanço do tempo, Bosi, em O ser e o tempo da poesia, localiza o "lugar como um topos negativo [...] uma sátira que não se compadece com as mazelas do presente" (1977, p. 163). Alocamse, sobretudo neste subsídio o mangue, o sertão e à Amazônia enquanto referenciais cronotópicos capazes de friccionar imagens alegóricas oriundas das inventivas dimensões político-filosóficas a que o romance insinua pela rememoração narrativa das personagens.

[...] o menino via refletir, com uma nitidez impressionante, as imagens de seu próprio ser tomando consciência do mundo. João Paulo, desencantado como se uma onda de tristeza súbita lhe afogasse a alma, suspira forte. E o ar que lhe entra agora pelas narinas já não é aquele ar impregnado dos cheiros cálidos e excitantes do sertão - cheiro de 
transpiração do gado [...] O que agora sente é um cheiro forte de lama podre, de terra morta em decomposição. (Castro, 1967, p. 44).

O herói-menino reabrena narrativa presente do pai Zé Luis e dos demais personagens, o baú de depauperamento e de silêncio do passado, aqui transformando em mote de resistência e de liberdade. Exala no romance um apelo centrífugo de esperança e de aventura. As memórias de outridade se deslocam do passado-presente, ofertando ao protagonista lampejos de libertação à aparente morbidez do charco. As inúmeras fabulações das personagens, pelas quais distorcem seus dramas de origem, ocupam o mesmo braço do mar, o de fuga de suas fomes, fome de água para Zé Luís, Maria, João Paulo e o menino; de oportunidades para Cosme - o paralítico, de justiça e igualdade para Mateus - o vermelho e Chico - o Leproso, de moral para Negra Idalina, dentre outros personagens e suas fomes diversas.

Evocando o passado de origem, o presente paradisíaco e o futuro incerto e, portanto, em devir, o mangue invoca um tempo de possibilidades em intercessão: da utopia sonhadora, que exige do protagonista João Paulo aventurar-se pelo mundo afora das memórias compartilhadas, a partir da experiência exotópica do amigo Cosme ${ }^{11}$, ou de resignação, caso siga o curso dos homens-caranguejo, sujeitados à vida monótona e gratuita do mangue, em um ciclo onde possivelmente "[...] o corpo de João Paulo que, com sua carne em decomposição, irá alimentar a lama que alimenta o ciclo do caranguejo", Castro (1967, p.177).

Yves Reuter, na Introdução à análise do romance (2004) entenderá que o tempo não é mais vivido como cíclico, visto que há uma constância do tempo-espaço, Para o crítico

\footnotetext{
${ }^{11}$ Sobre a exotopia, explica Bakhtin (1992, p. 45): “O excedente da minha visão contem em germe a forma acabada do outro, cujo desabrochar requer que eu lhe complete o horizonte sem lhe tirar a originalidade".
} 
Oliveira, Thiago Azevedo Sá de. O romance 'Homens e caranguejos' de Josué Castro: A contemporaneidade no tempo narrativo da memória.

(2004, p. 16), “Abandonam-se a repetição para se integrar categorias como a evolução, o progresso, o sentido da história. O herói constrói sua existência de sua predestinação". Logo, ganha o tempo no romance pelo efeito da cronotopia inserida formal e contextualmente em Homens e caranguejos.

Modificam-se nos espaços-tempos-personagens, a todo instante novos, a ação memorativa do infantil protagonista, ao longo do "jogo recíproco entre o olhar cheio de expectativas da criança e o olhar posterior do adulto que sabe da derrota destas expectativas", ilustra Silva (2010, p. 33), flui a memória como as águas do tempo e do antitempo, renascendo, avançando, sempre novo, conforme sugere o poema-epígrafe aqui anunciado.

\section{O plurilinguismo: traços do gênero romanesco e da estilização discursiva da personagem}

Análoga ao norte linguístico de Mikhail Bakhtin, que caracteriza o romance, como "um fenômeno pluriestilistico, plurilíngue e plurivocal"12, (2010, p. 73), são as unidades heterogêneas repousadas na tessitura josueniana. Resultante da elaboração literária que hibridiza diversas formas discursivas (canções populares, memórias do autor, poemas, contos e alusões históricas), o plurilinguismo desta ficção, ao passo que a alarga em elasticidade estrutural, propicia, ao nível da estilização do discurso, o perfil polifônico ${ }^{13}$

\footnotetext{
${ }^{12}$ Sobre as principais unidades estilísticas de composição do conjunto romanesco, Bakhtin destaca: "1. A unidade direta e literária do autor (em todas as suas variedades multiformes); 2. A estilização de diversas formas da narrativa tradicional oral (skaz); 3. A estilização de diversas formas da narrativa (escrita) semiliterária tradicional (cartas, diários, etc.); 4. Diversas formas literárias, mas que estão fora do discurso literário do autor: escritos morais, filosóficos, científicos, declamação retórica, descrições etnográficas, informações protocolares, etc.; 5. Os discursos dos personagens estilisticamente individualizados", (Bakhtin, 2010, p. 73-4).

${ }^{13}$ Para Stam (1993, p. 164), “O conceito de polifonia chama atenção para a coexistência, em qualquer situação textual ou extratextual, de uma pluralidade de vozes que não se fundem numa consciência única, mas existem em
}

Brasiliana - Journal for Brazilian Studies. Vol. 3, n.1 (Jul. 2014). ISSN 2245-4373. 
Oliveira, Thiago Azevedo Sá de. O romance 'Homens e caranguejos' de Josué Castro: A contemporaneidade no tempo narrativo da memória.

das personagens, desse modo mesclado pela transição ético-estética da palavra do autor $^{14}$.

Sinalizando para o que Hutcheon (1991, p. 142) vislumbra no conceito de 'metaficção historiográfica', isto é, como romance que desperta uma autorreflexão histórica dos eventos assimilados como "verdadeiros", Homens e caranguejos traça na experiência memorial de seguidos êxodos, o registro multiforme da fome, episódio que irmana as personagens, cada qual presa em seu propósito, no mesmo braço do rio onde a marginalidade é multiplamente aflorada na sinergia polifônica das vozes em diálogo.

Unindo as pontas de uma carreira literária que tem início no ano de 1935, com o livro O ciclo do caranguejo, no qual são publicados os contos "A cidade", "O despertar dos mocambos", "Solidariedade humana", "A seca", "João Paulo", "Ilha do Leite", "Assistência social", "Ciclo do caranguejo", dentre outros, Josué de Castro adensa em Homens e caranguejos, o diálogo de toda sua primeira matéria escritural, agora rearranjada no interior de uma composição mais robusta, um romance.

Com o auxílio de uma sinopse predecessora da personagem, no conto João Paulo ${ }^{15}$, publicado anos antes do romance, o protagonista é uma criança dotada de espirito empreendedor para o trabalho. No levantar sonolento após o alarde fabril que o

registros diferentes, gerando entre si um dinamismo dialógico".

${ }^{14}$ Para Bakhtin (2010, p. 119-120), “As palavras dos personagens, possuindo no romance, de uma forma ou de outra, autonomia semântico-verbal, perspectiva própria, sendo palavras de outrem numa linguagem, também podem refratar as intenções do autor e, consequentemente, podem ser, em certa medida, a segunda linguagem do autor."

${ }^{15}$ Ver Castro (1959, p. 29-30), "João Paulo era o filho mais novo do caboclo Zé Luís. E o mais trabalhador. [...] Menino bom e de juízo. No começo do ano passado, com nove anos apenas, o diabinho arranjou um emprego para ganhar dinheiro, servindo assim de adjutório para a família. Foi o padre Aristides passeando por afogados numa tarde de calor, viu a habilidade do menino para pegar caranguejo e contratou-o, logo, ali mesmo na beira do mangue, para ajudá-lo a pegar goiamum.”. A cena, extraída do conto João Paulo, é indicial para a composição ideológica da personagem romanesca. Em Homens e caranguejos, a mesma figuração narrativa é reorganizada sob a forma de capítulo, cap. III - "Da estranha maneira do padre Aristides fabricar tempestades para pegar guaiamu. Dos ingredientes utilizados e das consequências.".

Brasiliana - Journal for Brazilian Studies. Vol. 3, n.1 (Jul. 2014). ISSN 2245-4373. 
acorda, tal qual a um trabalhador adulto, o menino, como num jogo de perguntas e respostas, indaga ao pai - Zé Luis, a questão que encerra o silêncio das vozes alheias, os motivos que a levaram para o mangue, "- Pai, por que a gente veio morar aqui no mangue?", Castro (1967, p. 28).

Reinterpretando Walter Benjamin (1892-1940), para quem a “criança não brinca apenas de ser comerciante ou professor, mas também moinho de vento ou trem", (1985, p. 108), mergulha-se a fundo na natureza desbravadora do herói. Reluz na figura do narrador a tarefa de recuperar o que parece perdido. No plano dos recursos metafóricos da linguagem, a consciência da personagem vem à tona por palavras que remetem ao pensamento de evadir;

[...] sair vagando pelo mundo afora como os navios que passam ao largo da costa, soltando com indiferença um arrogante penacho de fumo por suas longas e grossas chaminés, que aos olhos de João Paulo pareciam ser a marca inconfundível do sexo desses navios: navios machos, de coragem indiscutível. [...] Para o menino precoce, no qual a puberdade começava a intumescer a carne e as ideias, um homem de verdade devia ser sempre assim, como um navio em alto-mar. Não se colar a nenhum porto. Apenas sentir o contato gostoso com a terra, apenas roçar as bordas do cais e partir de novo pelo mundo afora, em busca de novos cheiros, novos contatos com outras terras. (Castro, 1967, p. 44-5).

Adorno, apud Vaz (2005, p. 54), aborda o fragmento do romance pelo caráter adjacente da lembrança "que ilumina, com a violência da dor da impossibilidade de trazer de novo aquilo que uma vez foi perdido, a alegoria coagulada do próprio declínio 
(Untergang) [do narrador]." Como precedente irrecusável ao recobramento da experiência rememorada, o narrador afere, em discurso indireto livre, o que Benjamin (1977, p. 44), menciona em ensaio aplicado a Nikolai Leskov, "da impossibilidade de voltar ao que já acabou, mas da necessidade de reelaborar (perlaborar) a memória na experiência atualizada, mesmo que seja ela resultado de um naufrágio, de um declínio".

Em causa pela decadente exposição à pobreza do submundo da lama ${ }^{16}$, o périplo do herói tem começo como o de um viajante pueril, vagando nos meandros da memória e da "vida". Como quem nunca migrou do lugar de onde está para o qual deseja, "o outro lado do mangue [...] tão bonito, tão diferente [...] como se fosse um outro mundo"17, senão pelas estórias que imagina ou "ouve dizer", o menino reler nos vestígios de outrem, o substrato de liberdade que procura. A isto, Bakhtin posiciona,

A ação do herói do romance é sempre sublinhada pela sua ideologia: ele vive e age em seu próprio mundo ideológico (não apenas num mundo épico), ele tem sua própria concepção de mundo, personificada em sua ação e em sua palavra. (Bakhtin, 2010, p. 137).

No mundo diegético onde a ação ideológica da personagem é a palavra ouvida ou imaginada, o narrador constrói a imagem derradeira da protagonista e dos seres que a ela se interpõe, como "um artesão cuja matéria é a vida humana", diz Benjamin (1987, p. 409). Em categoria narrativa de câmera, descrita na leitura de Abdala Junior, sobre a

\footnotetext{
${ }^{16}$ No prefácio do romance, o autor se reporta à pobreza pela mimetização do êxodo rural, evento realizado por algumas das personagens formadoras do núcleo central da Aldeia Teimosa. O movimento migratório para uma comunidade urbana, periférica, localizada nos recônditos do mangue, à margem do progresso da cidade, consolida a metáfora da lama, "(n)as negras manchas demográficas da geografia da fome”, (Castro, 1967, p. 24).

${ }^{17}$ Castro, 1967, p. 32.
}

Brasiliana - Journal for Brazilian Studies. Vol. 3, n.1 (Jul. 2014). ISSN 2245-4373. 
Oliveira, Thiago Azevedo Sá de. O romance 'Homens e caranguejos' de Josué Castro: A contemporaneidade no tempo narrativo da memória.

tipologia de Norman Friedman (1995, p. 32) pelo efeito cinematográfico das narrativas "[..] que tentam transmitir flashes da realidade como se apanhados por uma câmera, arbitrário e mecanicamente", cada personagem é rememorada pelo narrador ou por outra personagem.

Além do herói, reduzindo o leque quantitativo das personagens às figuras centrais, fundadoras do exílio da Aldeia Teimosa, apresentam-se na ordem da narração, o Padre Aristides, Cosme - o paralítico, Zé Luis, Seu Maneca. Dos espelhos de Cosme ${ }^{18}$, aparecem Mateus - o vermelho, a Negra Idalina e Chico - o leproso.

Em conotação circunstancial, contígua à literatura de $\operatorname{cordel}^{19}$, o romancista marca de coralidade ${ }^{20} \mathrm{o}$ espírito popular atribuído às personagens. Nas feiras, nas rodas de conversa, a caminho do trabalho, nas festas, os sujeitos figurados entoam suas fabulações do mundo. Logo, as personagens de Homens e caranguejos são seres que contam e ouvem histórias. São sensíveis às expectativas criadas no juízo e na experiência legados pelo outro.

Periféricas à trajetória de João Paulo, o narrador nos cede a pintura de Zé Luís e Maria (pais de João Paulo), retirantes do sertão e sem maiores ambições da vida, Padre Aristides, o sacerdote cujo pecado confesso é a gula por guaiamu, Seu Maneca - quem por medo de morrer de fome no trabalho do canavial, emigra e, Cosme - o paralítico,

\footnotetext{
${ }^{18}$ No Cap. IX —De como João Paulo ficou conhecendo melhor os seus vizinhos através do espelhinho de Cosme, “o paralítico" engendra a caracterização de três personagens: Mateus - o vermelho, Negra Idalina e Chico - o leproso. (Castro, 1967, pp. 109-121).

${ }^{19}$ Grande parte dos capítulos é iniciada pela expressão "De como". Como exemplo, temos: $I$ - De como o corpo e a alma de João Paulo se foram impregnando do suco dos caranguejos. V- De como Zé Luis falou com Deus sem antes se benzer. A forma circunstancial se altera em apenas um caso, III —Da estranha maneira do Padre Aristides fabricar tempestades para pegar guaiamu. Dos ingredientes utilizados e das conseqüências.
}

20 Ler Mégevand, Martin. Coralidade. In: Urdimento. $\mathrm{N}^{\circ}$ 20, Set de 2013. Disponível em: http://www.ceart.udesc.br/ppgt/urdimento/2013/Urdimento\%2020/coralidade.pdf. Acesso: 26/02/2014.

Brasiliana - Journal for Brazilian Studies. Vol. 3, n.1 (Jul. 2014). ISSN 2245-4373. 
de quem os espelhos de mão com que se comunica com o mundo, servem de alegoria para o pensamento do herói.

Consistindo em liderança cerebral de toda a comunidade da Aldeia Teimosa, Cosme traz, em sua intuição crítica, as cicatrizes da experiência da vida e dos livros que já leu. A maturidade adquirida nas viagens que fez e, sobretudo, das adversidades e alegrias que "viveu" faz de Cosme um líder, consultado por todos. É com os "olhos aguçados do mundo lá de fora" que Cosme transmite a João Paulo suas frustrações e seus conhecimentos.

É também através de $\operatorname{Cosme}^{21}$ e de seus tempos áureos que João Paulo tem contato com a esperança da vida que não a de miséria, da qual nasceu e dela não consegue escapar. Reside nas prosas do amigo Cosme uma situação propiciadora de fuga.

Em primeiro grau, a importância da personagem Cosme o coloca no patamar de, dividir, junto ao narrador, a função de apresentar as personagens. Mateus - o Vermelho, o operário elevado à comunista, no engano decorrente da cor de seus cabelos, Chico - o leproso, preso ao seu mocambo na "clausura" de sua doença, e Negra Idalina, envergonhada pelo "desvirtuamento" da sua filha Zefinha, são confiados pelos créditos individualizados, estilisticamente dedutíveis do discurso cogitado por este ator linguístico.

No modo como a personagem encara a realidade, isto é, no subsolo das figurações estéticas, nota-se a afinidade discursiva de Cosme ao discurso científico

\footnotetext{
21 "Quando João Paulo ficou conhecendo, em todos os detalhes, a odisseia de Cosme em sua fracassada aventura para conquistar o mundo, cresceu ainda mais a sua admiração pelo amigo, e a sua curiosidade em ouvi-lo contar mais coisas de sua vida. E Cosme sempre satisfez esta curiosidade do menino. Sempre contou-lhe, não só as coisas maravilhosas do mundo que ele percorrera com suas pernas - a Amazônia - mas, também, as do mundo que percorrera com a cabeça, nos livros: todas as lembranças de suas leituras na mocidade." (Castro, 1967, p. 67).
}

Brasiliana - Journal for Brazilian Studies. Vol. 3, n.1 (Jul. 2014). ISSN 2245-4373. 
defendido pelo autor em suas obras de teor engajado às aspirações econômicas, políticas e sociais.

Ultimamente, Cosme procura explicar a Chico que a situação do povo está ficando cada vez mais difícil, que a fome aumenta cada dia e que o governo não toma a menor providência. Que os políticos montados no poder só pensam mesmo em encher a pança. Mas isto tudo vai acabar. Cosme informa que está a par da tempestade que a indiferença dos potentados está semeando na terra. Muito em breve a tempestade vai estalar por culpa deles. Por culpa dos donos da terra que não deixam os moradores cultivá-la para matarem sua fome. Por culpa dos donos da fábrica que pagam aos operários um salário de fome para que possam manter seus filhos viajando pela Europa e sustentar uma penca de mulheres nos apartamentos de luxo da cidade. E por culpa principalmente do governo, que vê tudo isto - toda a pouca vergonha dos ricos e toda a miséria do povo - e finge que não vê. (Castro, 1967, p. 120).

Virando a luminosidade de focalização para o protagonismo da criança, o romance fraciona o falso engajamento científico-político em linguagem de evocação. Ao lado disso, as reflexões de Maurice Habwachs (1877-1945), em A memória coletiva (1950), esteiam a configuração do romance e, da personagem, na circunstância arbitrária com que a memória perpassa os sentidos do discurso de caráter político pela assonância da abstração individualizada e de duração exígua. 
Como a criança seria capaz de atribuir valores diferentes às partes sucessivas do quadro que a vida lhe apresenta e, principalmente, por que se espantaria com os fatos ou os episódios que retêm a atenção dos adultos porque estes dispõem, no tempo e no espaço, de muitos termos de comparação? Uma guerra, um tumulto, uma cerimônia nacional, uma festa popular, um novo modo de locomoção - as obras que transformam as ruas de uma cidade podem ser pensadas de dois pontos de vista diferentes. São fatos singulares em seu gênero, que modificam a existência de um grupo. Entretanto, por outro lado, esses fatos transformam em uma série de imagens que trespassam as consciências individuais. Quando se retém apenas essas imagens, no espírito de uma criança elas poderão se destacar das outras por sua singularidade, seu fragor, sua intensidade; mas o mesmo não acontece com muitas imagens que não correspondem a acontecimentos de semelhante alcance. Uma criança chega à noite em uma estação de trens cheia de soldados. $\mathrm{O}$ fato de estarem retornando das trincheiras ou voltando para lá, ou simplesmente estejam em manobras, não impressionarão nem mais, nem menos. O que era de longe o canhão de Waterloo, se não um ribombar confuso de trovão? Um ser como a criancinha, reduzido a suas percepções, guardará de tais espetáculos apenas uma lembrança frágil de pouca duração. (Halbwachs, 2003, p. 79).

A maneira lúdica do brincar de menino faz de João Paulo, o arquiteto de um mundo cuja paisagem é montada como se fossem as peças de um jogo de quebra-cabeças. Feita a ressalva de que, no contato com o amigo Cosme e, na leitura das "vivências" dos 
outros $^{22}$ personagens, o protagonista é sucedido do universo das preocupações adultas, à altura da delimitação do narrador, para o herói, a imagem que vê, é sinônima das profundas comparações pontuadas nas linhas figurativas de paralelos de semelhança, se não vejamos;

[...] João Paulo dá um salto imprevisto das margens do mangue e de pé divisa à certa distância um grupo de pescadores de caranguejos que avançam, atolados até as coxas, na lama do mangue. São três homens jovens e morenos com o corpo todo coberto duma carapaça espessa de lama como se fosse uma verdadeira armadura. Aos olhos de João Paulo, estas figuras humanas aparecem como se fossem figuras de heróis das antigas histórias de cavaleiros armados que lhe contou Cosme. Como se fossem gigantes com o corpo fabricado com grandes blocos de barro, retirados do próprio mangue. Formados ali mesmo na lama como se formam e se criam os caranguejos na fermentação do charco. Para João Paulo, estes homens, cavaleiros da miséria, com suas armaduras de barro, e os caranguejos, com suas duras carapaças, são os heróis de um mundo à parte, são membros de uma mesma família, de uma mesma nação, de uma mesma classe: a dos heróis do mangue. E João Paulo se sente como se fosse um filho dessa família. Sente-se inconscientemente identificado com estes seres, fraternalmente ligado aos homens e aos caranguejos, conquistadores do mangue. (Castro, 1967, p. 45-6).

\footnotetext{
22 "Para que atinja a realidade histórica atrás da imagem, ela terá de sair de si mesma, terá de ser posta no ponto de vista do grupo, para que possa ver como tal fato marca uma data - porque entrou no círculo das preocupações, dos interesses e das paixões nacionais." (Halbachs, 2003, p. 80).
} 
A visão que esta personagem almeja a vida seduz a pedida de "ouvir a voz do infante e dialogar com ele", conforme prevê Márcia Cabral da Silva (2010, p. 27), em Infância e Literatura (2010). Neste volume, que realça a apreensão da criança no domínio literário ouve-se bastante da substância composicional da personagem João Paulo.Com a atenção julgada, a priori, por "desajeitada", a natureza do sujeito infantil é especificada pela estudiosa em harmonia às probabilidades predominantemente amarradas aos fundamentos teóricos de Walter Benjamin.

Repelindo-se da noção de infância datada da ideologia burguesa do século XVIII, período do qual, adverte Silva (2010, p. 37) “todos os esforços se concentram para conformar a natureza considerada ingênua, deformada e incompleta da criança", a autora extrai da reflexão benjaminiana o atalho conceitual inverso. Da observação que grafa sobre a brincadeira, depois de reportados os trechos de Benjamin, "As cores" e "O jogo das letras", presentes em "Infância em Berlim por volta de 1900", tem-se;

Esses trechos sugerem inúmeras possibilidades de leitura. Em "As cores" e "O jogo das letras", por exemplo, compreende-se que as crianças são as coisas que tocam. Brincar para elas adquire um significado essencial. Não se trata de pura imitação, nem apenas de contribuir para amadurecer e desenvolver faculdades mentais. Durante a brincadeira, a criança tem a possibilidade de tirar os objetos de sua função reificada, tão própria das sociedades de consumo. Agindo sobre aqueles objetos no ato de brincar, a criança imprime-lhes, fundamentalmente, um novo significado, que contribui para afirmar o lugar de quem produz - e não somente reproduz cultura. (Silva, 2010, p. 35). 
Oliveira, Thiago Azevedo Sá de. O romance 'Homens e caranguejos' de Josué Castro: A contemporaneidade no tempo narrativo da memória.

Na epígrafe derradeira de Benjamin (1984, p. 64), para quem, "sem dúvida, brincar significa sempre libertação. Rodeadas por um mundo de gigantes, as crianças criam para si, brincando, o pequeno mundo próprio", a tratativa da infância no herói josueniano cria um mundo particular no interior do universo discursivo do romance, sendo este, por si só, singular e diverso da referência da fome que toma emprestada e, reoxigena como linguagem.

Se levado a cabo à atuante participação do médico e político ativista do combate à fome, o romancista, esforça-se, portanto, para o papel consciente de quem sabe das artimanhas do ficcionista ${ }^{23}$. Para que o drama da fome seja validado, não na perspectiva do acadêmico que é senhor da questão, mas no subterfúgio de reelaboração das memórias de criança, a composição estilistica da protagonista-criança, alude a "incompetência infantil reveladora de uma verdade que os adultos não podem nem querem ouvir", corrobora Gagnebin (1994, pp- 92-3).

Pelo processo de intertextualidade explícito desde o prefácio, o romancista figura na arte que imprime a fisionomia de uma obra híbrida, que se mantém próxima da sociedade, sendo, contudo uma sublimação, estilisticamente livre e, por isso, formalmente autorreflexiva e contemporânea. Pesados os efeitos da dinâmica entre

23 “[...] não acredito em literatura neutra, literatura sem tendências, enquistada no absoluto dos cânones da arte. Sem contactos estranhos, sem raízes, sem ligações com os outros aspectos sociais que definem uma cultura. E, no entanto, o que é curioso, eu sou daqueles que creem na arte pela arte, enquanto criação consciente, individual do artista. Não vejo necessidade para o poeta, de andar metrificando sua ideologia, nem para o romancista, de jogar nas suas estórias os argumentos filosóficos de suas atitudes políticas. Sou contra os romances de tese. O artista verdadeiro não é obrigado a ser conscientemente um libelista, porta-voz dos sentimentos recalcados de angústia e de revolta dos oprimidos de uma determinada situação histórico-social. Exigir isto dele seria acabar com a arte como expressão de espontaneidade. $\mathrm{O}$ artista pode ver e sentir o mundo livremente, sem compromissos diretos com quaisquer princípios filosóficos. Na ignorância absoluta de todos os sistemas de interpretação das verdades cósmicas. Um único compromisso, e este de vida ou de morte, é o que deve manter o artista para consigo mesmo, para com suas próprias impressões sensoriais, para com sua experiência sensível". (Castro, 1959, p. 59-60).

Brasiliana - Journal for Brazilian Studies. Vol. 3, n.1 (Jul. 2014). ISSN 2245-4373. 
escrituras de composições distintas, modula-se pelas memórias um universo diegético indicialmente sugestivo de tempos e espaços onde as personagens transitam famintas, receosas no silêncio que, segundo Salgueiro (2012, p. 289) ecoa a “impossibilidade radical de re-apresentação do vivido/sofrido".

Sentindo que a história que vou contar é uma história magra, seca, com pouca carne de romance, resolvi servi-la com uma introdução explicativa que engordasse um pouco o livro e pudesse, talvez, enganar a fome do leitor - a sua insaciavél fome de romance. Foi no fundo uma espécie de sublimação deste complexo de um povo inteiro de famintos, sempre preocupado em esconder ou, pelo menos, em disfarçar a sua fome eterna, que acabei fazendo uma copiosa introdução a este magro romance que tem, como personagem central, o drama da fome. Assim, por força das circunstâncias, encontrará o leitor, neste livro, muita explicação e pouco romance. Pouco, mas o suficiente para dar ao livro o gosto e o cheiro fortes do drama da fome que é, no fundo, a carne desta obra. (Castro, 1967, p. 11).

Em face do relevo temporal, Homens e caranguejos ambienta-se em meados do século XIX, a partir da grande seca de 1877, como uma ficção mimética da fome. O contexto histórico da obra (1966), do Brasil no pós-Golpe de 64 clama, contudo, ao resguardo, de Adorno (1980, p. 270), que vê na obra de arte "um espaço ímpar, onde na transcendência estética reflete-se o desencantamento do mundo". Pretende ele, com esta posição, ir além das teses que determinariam o grau de singularidade de uma composição pelo quão a lírica representasse somente as fontes externas que lhe seriam agregadas. Adorno 
(2003, p. 67) sugere a hipótese de pensar "em que a obra de arte lhe (a) obedece (sociedade) e em que a ultrapassa", assumindo uma mediação, a de pensar como a obra de arte é capaz de aprofundar no interior do organismo universal da linguagem o todo de uma sociedade.

Por palatável que seja a crítica endossada por Jameson (1992, p. 15), “em favor da prioridade da interpretação política dos textos literários", a construção do romance josueniano se afina com a leitura simbólica e social da realidade. Watt (2007, p.13) permeia esta aproximação no momento em que compara a prosa de Defoe, Richardson e Fielding e a produção que os antecede, afirmando que realismo destes "não está na espécie de vida apresentada, e sim na maneira como a apresenta".

Sintomático da cooperação do contexto aplicado ao texto, Tânia Pellegrini explana, no ensaio 'Realismo: postura e método' (2007), para que se perceba como postura e não como reconstrução descritivista intrínseca do legado realista do século XVIII, o realismo presente na prosa contemporânea.

Como bem se coaduna ao nexo da contemporaneidade, o romance Homens $e$ caranguejos foi duramente censurado pelo regime ditatorial, uma vez queprovocou, à luz de Pellegrini (2007, p. 138), “uma forma particular de captar a relação entre os indivíduos e a sociedade". Na ficção contemporânea, o plurilinguismo miscigena a linguagem da fome como um universo "refratado" de questões estéticas, mas também tenras ao envolvimento do homem em suas urgências sociais e afetivas. No contato entre história, o narrar e a memória, a lembrança confere ao herói, reaver o passado problemático de seus próximos.

O resgate de um acontecimento feito através da obra de arte sempre gera polêmica, pois nessa "visita" ao passado podem-se descobrir 
"verdades" até então não reveladas, devido às relações de interesse e poder de "grupos" conservadores. Durante muito tempo, precisamente todo o século XIX, a literatura produziu o romance realista que, em geral, não partia do pressuposto de que a "realidade" social vivida fosse ambígua ou múltipla, ou seja, a partir de uma reflexão cotidiana focada na sensibilidade humana, o sujeito "aceitava" essa realidade como algo natural e invariável, a natureza precária do indivíduo como herança intransponível. Entretanto, a História da Literatura contemporânea, aliada aos modelos progressistas de retratar a arte pelas diferenças, como é o caso da literatura pós-colonialista, verificou que era necessário problematizar, a sua maneira, seu contexto social. Por motivos como esse, o final do século XX foi marcado por uma atomização das camadas eruditas da arte e firmou-se a consciência de que a história vinha sendo contada "de cima", sob um misto de interesses e ideologia dos historiadores. (Jacomel; Silva, 2007, p. 740).

Redirecionada a arte sob o ângulo que tenta resguardar o elo de lucidez e atenção para com a sociedade, é de interesse avaliar em que medida os elementos materiais se mantêm coerentes e expressivos quando interpenetrados junto aos elementos formais. Ao seguir esta direção, articula-se a possibilidade de enxergar a arte literária movendose, a priori, no mais puro processo de individuação da realidade a fim de atingir não apenas um dado próximo ao social que lhe seja referência e reconhecimento, mas indo além, uma vez que revela valores e emoções da sociedade no universo de signos e de imagens. 


\section{Conclusão}

O estado efêmero comum às memórias das personagens em Homens e caranguejos atua nos componentes textuais da narrativa, conferindo a esta produção literária um perfil contemporâneo, pautado na ideia de que a ficção recria o universo caótico da fome em sua forma constante, todavia, notavelmente descompassada em face linguística. Verifica-se uma escritura que, em termos sintáticos e semânticos, acena para o horizonte aberto de uma fabulação recordativa fragmentada. Há, assim, a falsa impressão de que, em termos de estruturação escritural, a lacuna de que algo se perde no caminho, palavras se repetem, entretanto, tal sensação é efeito do disforme consciente/inconsciente, do real/ficcional, do eu/outro, do autor/narrador, em suma, das lembranças transpostas do cenário de sangue e lama para o palco multidimensional da linguagem enlameada.

As imagens simbólicas das fomes, em trânsito, simulam tempos-espaços sinestésicos situados no limite fronteiriço e acolhedor do cronotopo mangue. Balbucia no clamor lúdico do protagonista-menino, sedento por aventuras e brincadeiras, uma relação intempestiva em que o recordar é configurador da catarse, do sujo e desumano passado, do outro, como catalisador de um romance que alimenta o futuro de nostalgia, de esperança e de humanidade. Na posição do narrador onisciente, que se esforça para preencher os vazios que a memória das personagens tenha sido falha, alterna discursivamente na figura de um eu-protagonista coletivizado, a natureza questionadora e inquietante que nutre o exercício da vida e da ficção, na travessia faminta de seus inerentes porquês.

\section{Referências:}


Abdala Júnior, Benjamin. Introdução à análise da narrativa. São Paulo: Scipione, 1995.

Adorno, T. Posições do narrador no romance contemporâneo In: Os Pensadores, São Paulo: Abril, 1980.

. Notas de Literatura I. Tradução e apresentação: Jorge M. B. de Almeida. São Paulo: Duas cidades; Ed. 34, 2003.

Aeurbach, Erich. Mimesis: a representação da realidade na literatura ocidental. 4. ed. São Paulo: Perspectiva, 2002.

Amado, Jorge. Uma Testemunha de Vista Depõe... In: O Drama Universal da Fome. Rio de Janeiro: Ascofam, 1958. p. 347-349.

Bakhtin, Mikhail. Estética da criação verbal. São Paulo: Martins Fontes, 1992.

. A estilística contemporânea e o romance. In: Questões de Literatura e de Estética. 6. Ed. Trad. do russo: Bernardini, A.F; Pereira Júnior, J; Góes Júnior, A; Nazário, H.S; Andrade, H.F. São Paulo: Hucitec, 2010.

. Marxismo e filosofia da linguagem. São Paulo: Hucitec, 1995.

. Os estudos literários hoje (Resposta a uma pergunta da revista Novi Mir). In:__. Estética da criação verbal. Trad. Paulo Bezerra. 4. ed. São Paulo: Martins Fontes, 2003, p. 362-363.

Bauman, Zygmunt. Modernidade líquida. Rio de Janeiro: Jorge Zahar, 2001.

Berman, Marshall. Tudo que é sólido se desmancha no ar - A aventura da modernidade. Trad.Carlos Felipe Moisés e Ana Maria L. Ioriatti. São Paulo: Companhia das Letras, 1986.

Benjamin, Walter. Reflexões: a criança, o brinquedo, a educação. São Paulo. Summus, 1984. . Obras escolhidas I. São Paulo: Brasiliense, 1985. 
. Obras escolhidas II. São Paulo: Brasiliense, 1987.

- Angelus Novus. In: Vaz, Alexandre Fernandez. Educação em RevistaSubjetividade, memória, experiência: sobre a infância em alguns escritos de Walter Benjamin e Theodor W. Adorno. n.6, p.51-66, 2005.

Calado, Eliana Alda de F. A estrutura textual do romance contemporâneo: uma análise de As pessoas dos livros, de Fernanda Young. Graphos, João Pessoa, v. 6, n. 2/1, jun./dez., 2004.

Calvino, Ítalo. Seis propostas para o próximo milênio. Trad. Ivo Barroso. São Paulo: Companhia das Letras, 1990.

Candido, Antônio. Literatura e Sociedade. 7. ed. São Paulo: Nacional, 1985.

Castro, Josué de. O Nordeste e o romance brasileiro. In: Documentário do Nordeste. 2. ed. São Paulo: Brasiliense, 1959.

Castro, Josué Apolônio de. Homens e Caranguejos. 1. Ed. São Paulo: Brasiliense, 1967.

Cortázar, Júlio. Valise de cronópio. Trad. Davi Arrigucci Júnior e João Alexandre Barbosa. São Paulo: Perspectiva, 1993.

Dimas, Antônio. Espaço e romance. 2. ed. São Paulo: Ática, 1987. p.38-41.

Estève, Michel (Org.). Études Cinématographiques: le "cinema nôvo" brésilien. Paris: Lettres Modernes, Minard, 1972.

Genette, Gerard. Discurso da narrativa. 3. ed. Lisboa: Vega, 1995.

Gagnebin, Jeanne Marie. História e narração em Walter Benjamin. São Paulo: Perspectiva/Fapesp/Ed. da Unicamp, 1994.

Haynes, Débora J. Bakhtin and the visual art. Cambrige: University Press. 1993.

Halbwachs, Maurice. A memória coletiva. Trad. Beatriz Sidou. São Paulo: Centauro, 2003. 
Hutcheon, Linda. Metaficção historiográfica: O passatempo do tempo passado. In: Poética do Pós-Modernismo - História, Teoria e Ficção. Trad. Ricardo Cruz. Rio de Janeiro: Imago, 1991.

Kiffer, Ana Paula. Graciliano Ramos e Josué de Castro: um debate acerca da fome no Brasil. Via Atlântica, São Paulo, n. 13, páginas, jun.2008.

Jacomel, Mirele Carolina Werneque; Silva, Marisa Correa. Discurso histórico e discurso literário: o entrelace na pespectiva da metaficção historiográfica. In: Anais do Celli Colóquio de estudos lingüísticos e literários. 3, 2007, Maringá, 2009, p. 740-748.

Jameson, Fredric. O inconsciente politico: a narrativa como um ato socialmente simbólico. Trad. Valter Lellis Siqueira. São Paulo: Ática, 1992.

Melo, Cimara Valim. O lugar do romance na literatura brasileira contemporânea. 1. ed. São Paulo: Annablume, 2013.

Nietzsche, Friedrich. Segunda consideração Intempestiva: Sobre a utilidade e os inconvenientes da História para a vida. In: Escritos sobre a história. Rio de Janeiro: PUCRio; São Paulo: Loyola, 2005.pp. 59-69.

Nunes, Benedito. O drama da linguagem. 2. ed. São Paulo: Ática, 1995.

Otávio, Garibaldi. Banguê. In: O girassol. Recife: CEPE, 2009, p. 16.

Pellegrini, Tânia. Realismo: postura e método. Letras de Hoje, Porto Alegre, v.42, n.4, p.135-155, dez.2007.

Ricoeur, Paul. A memória, a história, o esquecimento. Tradução: Alain François. Campinas: UNICAMP, 2007.

Reuter, Yves. Introdução à análise do romance. São Paulo: Martins Fontes, 2004.

Rosenfeld, Anatol. Texto/Contexto. 3. ed. São Paulo: Perspectiva, 1976.

Rebouças, Jaqueline Argolo. Memórias e identidades: entre as representações de uma cidade (Amargosa, 1930-1950). In: III Encontro Baiano de Estudos em Cultura- Ebecult, 2012, Cachoeira - BA. Artigos Completos, 2012. 
Salgueiro, Wilberth Claython Ferreira. O que é Literatura de testemunho (e considerações em torno de Graciliano Ramos, Alex Polari e André du Rap). Matraga, Rio de Janeiro, v. 19, p. 284-303, 2012.

Sartre, Jean-Paul. Que é a literatura? Trad. Carlos Felipe Moisés. São Paulo: Ática, 1989.

Silva, Márcia Cabral da. Infância e literatura. Rio de Janeiro: EdUERJ, 2010.

Spinelli, Egle Müller. Estudos cronotópicos em narrativas audiovisuais. Revista Galáxia, São Paulo, n. 10, p. 31-50, dez. 2005.

Stam, Robert. "Mikhail Bakhtin e a crítica da cultura de esquerda". In: Kaplan, A. E (org.). O mal estar no pós-modernismo. Rio de Janeiro: Zahar, 1993.

Vaz, Alexandre Fernandez. Subjetividade, memória, experiência: sobre a infância em alguns escritos de Walter Benjamin e Theodor W. Adorno. Educação em Revista, n. 6, p.51-66, 2005. Disponível em: http://www2.marilia.unesp.br/revistas/index.php/educacaoemrevista/article/viewFile/598/481. Acesso: 22/01/2014.

Watt, Ian. A ascensão do romance: estudos sobre Defoe, Richardson e Fielding. São Paulo:Companhia das Letras, 2007.

Young, Fernanda. As pessoas dos livros. Rio de Janeiro: Objetiva, 2000. 